\title{
Textbook To Reality: Using Corporate Earnings Reports As An Effective Teaching Tool For A Business Capstone Course
}

\author{
Manzoor E. Chowdhury, Lincoln University, USA
}

\begin{abstract}
Business curriculums in many universities now include a senior Capstone course that integrates topics or materials from all business areas. This capstone course is designed to teach the skills of strategic thinking and analysis rather than mere facts or concepts. With that goal in mind, the ideal course is structured in such a way so that students get an opportunity to apply their knowledge from all previous courses taken before the capstone course. Instructors around the country use a variety of teaching tools in a capstone course that include simulation games, group projects, individual projects or paper, and/or case studies. One of the effective teaching tools in a capstone course is quarterly or annual earnings reports submitted to the SEC (Securities and Exchange Commission) by all publicly traded companies. Although earnings reports are used by some instructors as a reference or as part of a case study, it has not been widely used in a way that is demonstrated in this paper. The earnings reports have a rich array of information that can be used to teach business concepts from every business discipline - accounting, economics, finance, human resource management, international business, or marketing. Going through a detailed earnings report exposes students to a real world scenario, teaches them how to read between the lines, and enhances their critical and strategic thinking process. It is also a great way to brush up their knowledge from all previous courses which helps them to retain the knowledge and to do well on the business exit exam. This paper demonstrates an approach or method where students use business concepts, theories, financial ratios, and formulas using actual company data from an annual Earnings Report of a company submitted to the SEC. The idea presented here is not mutually exclusive of other tools used in a capstone course but rather contributes to learning if can be used simultaneously.
\end{abstract}

Keywords: Capstone Project; Capstone Course; Exit Exam; SEC; Earnings Report

\section{INTRODUCTION}

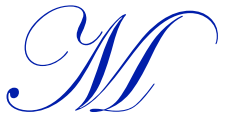

any Business Programs in the United States now require graduating seniors to take an exit exam as part of the accreditation requirement for continued assessment. Administered by educational services companies such as ETS or Peregrine Academic Services, these exit exams include questions from economics, finance, marketing, management, international business, accounting, management information systems, and other business disciplines. The scores from these exit exams are used by business programs to assess their students and to determine whether any changes are necessary to increase student performance.

Along with this exit exam, business curriculums in many universities now include a senior Capstone course that integrates topics or materials from all business areas. This capstone course - typically named as Strategic Management in most universities - is designed to teach the skills of strategic thinking and analysis rather than mere facts or concepts. It is a culminating academic experience that ties together all previous courses in an academic discipline and facilitates transition to a chosen career.

Instructors teaching the Strategic Management capstone course usually use one of the following methods or approaches to engage their students and to evaluate them. These are case studies, games or simulation, or a general research paper. All are effective and popular teaching tools, however, they don't integrate or combine ideas or 
concepts from all business areas. A Capstone Project can be designed in such a way where students use business concepts, theories, financial ratios, and formulas using actual company data from the Earning Reports submitted to the SEC (Securities and Exchange Commission) every quarter. Instructors can design a course project where students not only use the income statement and balance sheet to compute financial ratios but also apply their knowledge from almost every business disciplines. These questions can be selected depending on the type and size of the company as well as the specific company data that are given to students to analyze the company. This paper demonstrates this idea using Starbuck's financial data from its Annual Report. Such a balanced Capstone Project goes hand in hand with the exit exam providing students an opportunity to "brush up" their knowledge learned in every business course as well as giving the business programs an additional assessment tool to assess their students and programs for accreditation.

\section{LITERATURE}

Not all papers related to case studies, simulation, and other methods fall into one category with a common theme. This is why an attempt is made here to cite a sample of studies that are relevant for this research. There are some studies that show the benefits and effectiveness of using simulation and games. Salas, Wildman, \& Piccolo (2009) suggest that simulation-based training (SBT) offers many advantages as an approach for management education, and in an effort to guide and encourage its appropriate use, they provided several practical guidelines regarding how best to implement simulation-based training in the classroom. Kendall and Harrington (2003), in their empirical study show that the use of management computer simulation cases facilitates greater educational development than does the use of written cases (or a combination) as perceived by hospitality students in a capstone strategic management course. Tomson and Dass (2000) investigated the relative contribution of simulations and case studies for improving students' self-efficacy in strategic management. Using pre-and posttest data from a sample of 252 students, the authors conclude that simulations result in significantly higher improvements in self-efficacy than case studies. The study by Stephen, Parente, and Brown (2002) provide promising evidence that the large-scale simulation approach is effective in helping students recognize the importance of integrating functional knowledge in strategic management. Mitchell (2004) compared the effectiveness of two different strategic management course designs: one centered on case discussions and the other combining a computer-based simulation with some cases. Both course designs produced statistically equivalent learning outcomes. Adobor and Daneshfar (2006) showed that the nature of the simulation and team dynamics affected learning and performance. The study demonstrated that carefully choosing simulations could affect their effectiveness. In line with the idea presented in this paper, Kachra and Schnietz (2008) argue that the traditional strategic management course structure does relatively well at developing theoretical and applied integration skills but do poorly in developing practical integration skills - the very skills increasingly demanded by employers. They suggest reorganizing the strategy capstone course along the levels of managerial decision making and emphasizing pedagogies that employ rich-enough cases and business simulations to better develop integration skills. Thavikulwat and Pillutla (2010) in their study considered two principles of simulation design (simple rules and smart algorithms) and three essential attributes (choice of industries, employer-employee relationships, and real markets for products and participant services) for strategic management business simulations. They applied these considerations and a constructivist approach to develop a computer-assisted simulation and suggest that computer-assisted simulations developed through a constructivist approach may be used to advance the discipline of strategic management.

\section{A BETTER INTEGRATED CAPSTONE PROJECT: AN ILLUSTRATION}

Instructors teaching Strategic Management use case studies, simulation games, and a variety of tools to teach strategic management concepts in the capstone course. These methods are not mutually exclusive, and an instructor can use some or all of these methods to develop a capstone project. The idea presented below does a better job in integrating business concepts from all business disciplines. By their senior year, many students forget what they learned from business courses during freshmen or sophomore years. The capstone course is typically taught by a management faculty who may not have expertise in economics, finance, marketing, or accounting. The following is an example of a capstone project that integrates many essential concepts from all business courses, and was developed by consulting with faculty who teaches accounting, economics, management, finance, and marketing. 
Students were asked to go through an Annual Earnings Report of Starbucks Corporation. To be able to understand an annual report of a major company (or to know how to "read between the lines"), a student must have the knowledge from all required major business courses. This example gives them a chance to review or "brush up" those concepts. Students then answer a series of questions based on Starbucks' earnings report. The answers can be found directly from the earnings report or from further research on Starbucks' company information.

Table 1. Illustration of Management Concepts

\begin{tabular}{l|l}
\hline \multicolumn{1}{c|}{ Topic } & \multicolumn{1}{c}{ Task } \\
\hline External Competitive Analysis & $\begin{array}{l}\text { Based on Item 1A (Risk Factors) discussed on Page 10 of the } \\
\text { Annual Report, conduct an external analysis using Porter's } \\
\text { Five Forces. }\end{array}$ \\
\hline Internal Analysis & $\begin{array}{l}\text { SWOT analysis, VRIO analysis, and a Value Chain Analysis. } \\
\text { According to the Annual Report, “... in November 2013, we } \\
\text { made the strategic business decision to commit to hiring } \\
10,000 \text { veterans and military spouses over the next five years.” } \\
\text { What are some activities can you find on the Annual Report } \\
\text { that shows Starbucks is committed to corporate social } \\
\text { responsibility. }\end{array}$ \\
\hline Corporate Social Responsibility & $\begin{array}{l}\text { Recent backlash about Starbucks' conversation on race } \\
\text { relations. Why and what went wrong? How would you have } \\
\text { approached it? }\end{array}$ \\
\hline
\end{tabular}

Table 1 shows some of the frequently used topics in a Strategic Management course. Porter's Five Forces, SWOT, VRIO, Value Chain Analysis, and Corporate Social Responsibility are discussed in almost every management book. However, in this example, the students are asked to use these concepts specifically for Starbucks Corporation. This is more "hands-on" and "real world" rather than just reading these concepts in the text book.

Table 2. Illustration of International Business Concepts

\begin{tabular}{l|l}
\hline \multicolumn{1}{c|}{ Topic } & \multicolumn{1}{c}{ Task } \\
\hline Global Entry Strategy & $\begin{array}{l}\text { Starbucks has two types of stores - (a) company } \\
\text { operated stores and (b) licensed stores. Which country } \\
\text { has the highest number of licensed stores? What are the } \\
\text { main advantages and disadvantages of a } \\
\text { licensing/franchising strategy? }\end{array}$ \\
\hline Cultural Awareness & $\begin{array}{l}\text { Which country has the highest number of total stores } \\
\text { (both company operated and licensed combined)? Can } \\
\text { you discuss Hofstead's culture dimensions and scores } \\
\text { for this country and what are some of the key cultural } \\
\text { aspects that management must be aware of when } \\
\text { expanding business in this country? }\end{array}$ \\
\hline $\begin{array}{l}\text { Compared to the previous year, the licensed stores } \\
\text { revenue increased by 20\% in 2013. What were the main } \\
\text { reasons for this increase? Answer: Licensed store } \\
\text { revenues contributed \$203 million to the increase in total } \\
\text { net revenues in fiscal 2012, primarily due to higher } \\
\text { product sales to and royalty revenues from our licensees, } \\
\text { resulting from improved comparable store sales and the } \\
\text { opening of } 665 \text { net new licensed stores over the past } 12 \\
\text { months. }\end{array}$
\end{tabular}


A few example questions from International Business are presented in Table 2. Licensing, franchising, along with other entry strategies are very important concepts especially in today's world where companies are exploring opportunities to enter foreign markets. Starbucks has significant international presence where some of Starbucks stores are company operated stores and some are operated by franchisees. The questions in Table 2 helps students to understand how and where Starbucks' foreign revenue is generated. Hofstede's culture dimensions are covered in every international business course and is a very useful tool to analyze and understand a country's culture. The second question in Table 2 is a great way to brush-up or relearn Hofstede's culture dimensions covered in an introductory Global Business course.

Table 3. Illustration of Finance Concepts

\begin{tabular}{l|l}
\hline \multicolumn{1}{c|}{ Topic } & \multicolumn{1}{c}{ Task } \\
\hline Ratio Analysis & Current Ratio, Quick Ratio, Debt/Equity Ratio, other ratios. \\
\hline Growth/Trend & Year-over-Year growth, Sequential growth. \\
\hline & $\begin{array}{l}\text { EPS for fiscal 2013 decreased to \$0.01, compared to EPS of } \\
\$ 1.79 \text { in fiscal 2012. What was the reason behind this sudden } \\
\text { drop in EPS? }\end{array}$ \\
Earnings per Share (EPS) & $\begin{array}{l}\text { Answer: Fiscal year 2013 results include a pretax charge of } \\
\end{array}$ \\
& $\begin{array}{l}\text { Foods Global, Inc. This charge reduced EPS by \$2.25 per } \\
\text { share in fiscal 2013. }\end{array}$ \\
\hline
\end{tabular}

Knowledge of a company's financial indicators and being able to conduct ratio analysis to investigate a company's financial health is a great skill valued by potential employers. The examples in Table 3 asks students to calculate important financial ratios, conduct a trend analysis using year-over-year growth and sequential growth, and analyze and explain Earnings Per Share (EPS) figures reported in the earnings report of Starbucks corporation.

Table 4. Illustration of Marketing Concepts

Topic Task

In 2013, what percent of Starbucks' total net revenue was spent on advertising? Is this lower or higher than what comparable large companies typically spend on advertising Advertising each year?

Answer: Starbucks spent a paltry $\$ 205$ million on advertising on $\$ 14.9$ billion in net revenue or approximately $1.3 \%$. McDonald's spends about $10 \%$.

If there is one company that should have failed in China, it would be Starbucks. China has thousands of years of history drinking tea and a strong culture associated with it. No one could have guessed that Chinese would ever drink coffee Global Marketing Strategy instead of tea.

Yet, Starbucks has successfully opened more than 570 stores in 48 cities since it first entered China twelve years ago. Building on this momentum, it plans to open 1,500 stores by 2015 . What did Starbucks do right in China?

There are many marketing issues and problems that students can take and discuss from the earnings report. These are real-world examples in the context of a specific company such as Starbucks. Two marketing questions are presented in Table 4. The first one is straight forward - requiring students to find the percent of Starbucks' advertising expense compared to similar companies. The second question requires more research and thinking on Starbucks' marketing strategy and challenges in China which has a long history of drinking tea rather than coffee. 
Table 5. Illustration of Economics Concepts

\begin{tabular}{l|l}
\hline \multicolumn{1}{c|}{ Topic } & \multicolumn{1}{c}{ Task } \\
\hline Market structure/Market Power & $\begin{array}{l}\text { According to published sources, the market share of coffee } \\
\text { chains are: Starbucks 32\%, Dunkins' Brands 16\%, and all the } \\
\text { rest 52\%. Calculate the Herfindahl-Hirschman Index (HHI). } \\
\text { What type of market structure Starbucks is part of? }\end{array}$ \\
\hline Elasticity/Price Discrimination & $\begin{array}{l}\text { Do you ever notice that the price for a tall basic type coffee at } \\
\text { Starbucks or McDonald's 8 oz. regular coffee never change too } \\
\text { much? Prices on most other sizes and beverage types go up } \\
\text { significantly, but these entry level sizes seem to stay the same. } \\
\text { Can you explain this price strategy by using some economic } \\
\text { concepts/theory? }\end{array}$ \\
\hline International Economics & $\begin{array}{l}\text { Starbucks is a global company and have transactions in other } \\
\text { currencies, primarily the Canadian dollar, Japanese yen, } \\
\text { Chinese renminbi, British pound, and euro. How does } \\
\text { Starbucks minimize the risk from foreign currency exposure? }\end{array}$ \\
\hline
\end{tabular}

Undergraduate business students typically take introductory economics courses (micro and macro) during freshmen and sophomore years. Many don't realize that economic concepts are not always theoretical but as important and useful as business concepts. Entry level business analysts are expected to have a solid foundation in economics and economic concepts used frequently in the business world. Three questions are presented in Table 5 that are related to market structure/ Herfindahl-Hirschman Index, elasticity and price discrimination, and risk and foreign currency exposure.

Table 6. Illustration of Accounting Concepts

\begin{tabular}{l|l}
\hline \multicolumn{1}{c|}{ Topic } & \multicolumn{1}{c}{ Task } \\
\hline Reporting EPS & $\begin{array}{l}\text { Is it a requirement that Starbucks' earnings per share (EPS) } \\
\text { must appear on their income statement? }\end{array}$ \\
\hline Researching a Specific Entry on a Statement & $\begin{array}{l}\text { On Starbucks 2014 Consolidated Statement of Earnings, } \\
\$ 20.2 \text { million is shown as a credit entry for the litigation } \\
\text { charge related to Kraft Foods litigation case. Explain the } \\
\text { details behind this entry. }\end{array}$ \\
\hline Calculating Goodwill & $\begin{array}{l}\text { Calculating a dollar figure for Goodwill is a complicated } \\
\text { process and many factors influence this calculation. On Dec } \\
31,2012, \text { Starbucks acquired 100\% of the outstanding shares } \\
\text { of Teavana. How did Starbucks derive the } \$ 467.5 \text { million of } \\
\text { goodwill related to that transaction and what does this number } \\
\text { represent? }\end{array}$ \\
\hline
\end{tabular}

Table 6 presents a few accounting questions that students can work on using Starbucks' earnings report. These relate to reporting Earnings Per Share, a \$20 million credit entry for the Kraft Foods litigation charge, and deriving a goodwill amount based on the Teavana acquisition in 2012. There are many more accounting questions that can be used from the Income Statement and Balance Sheet of Starbucks Corporation.

\section{CONCLUSION}

This paper shows that a more balanced and better integrated Capstone Project can be designed for a capstone course using company earnings report submitted to the SEC. Because the earnings reports cover a wide range of company business information - finance, marketing, management, accounting, human resource management, international business - a better understanding of the earnings reports can prepare students for a wide range of management jobs. Another obvious benefit of using earnings reports is that there is a long list of companies to choose from, so an instructor will never run out of teaching materials! Furthermore, besides improved student learning, this approach has also other advantages that are related to assessment (senior exit exam) and accreditation. 
The example demonstrated in this paper is not mutually exclusive and can be used along with simulation, case studies, research paper, and other methods or tools used in a capstone course. Students learning to analyze company earnings report have higher satisfaction (as reflected in senior exit survey) with the course as they feel they are exposed to more real-world information that can be useful in their future jobs.

\section{AUTHOR BIOGRAPHY}

Manzoor Chowdhury is an Associate Professor of Business \& Economics at Lincoln University. He received his Ph.D. in Applied Economics from Texas A\&M University and had worked in the private sector (Sprint-Nextel, AOL-Time Warner) for over 10 years before coming to the Academia. He is the recipient of the Universities Council on Water Resources outstanding dissertation award, best paper and best presentation awards in many conferences, has published over 15 journal articles, and presented over 20 papers in professional conferences.

E-mail: chowdhurym@lincolnu.edu

\section{REFERENCES}

Tompson, George H., and Dass, Parshotam. (2000). Improving Students' Self-Efficacy in Strategic Management: The Relative Impact of Cases and Simulations, Simulation \& Gaming, 31: 22-41

Kendall, K. W., and Harrington, Robert J. (2003). Strategic Management Education Incorporating Written or Simulation Cases: An Empirical Test. Journal of Hospitality \& Tourism Research, 27: 143-165

Salas, Eduardo, Wildman, Jessica, and Piccolo, Ronald. (2009). Using Simulation-Based Training to Enhance Management Education. Academy of Management Learning and Education, Vol 8: 559-573

Mitchell, Rex. (2004). Combining Cases and Computer Simulations in Strategic Management Courses. Journal of Education for Business, Vol. 79, issue 4.

Stephen, John, Diane Parente and Randy Brown. (2002). Seeing the Forest and the Trees: Balancing Functional and Integrative Knowledge Using Large Scale Simulations in Capstone Business Strategy Classes, Journal of Management Education, vol. 26, number 2, 164-193

Adobor, Henry and Alireza Daneshfar. (2006). Management Simulations: Determining their Effectiveness, Journal of Management Development, Vol. 25, \#2, 2006. pp. 151-168

Kachra, Ariff and Schnietz, K. (2008). The Capstone Strategy Course: What Might Real Integration Look Like? Journal of Management Education, August 2008, vol. 32, \#4, 476-508.

Thavikulwat, Precha and Pillutla, Sharma. (2010). A constructivist approach to designing business simulations for strategic management, Simulation \& Gaming April 1, 2010 41: 208-230 